
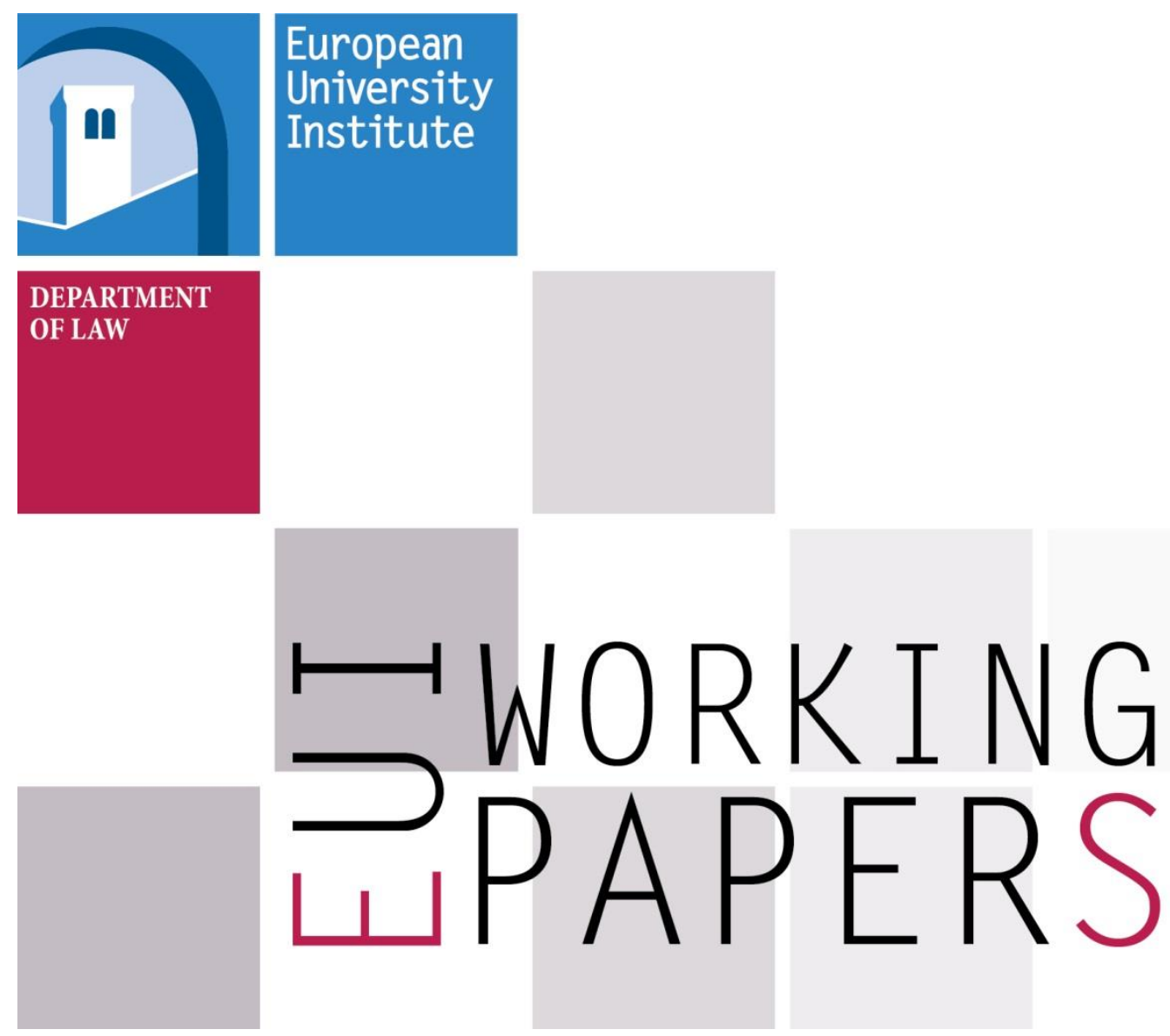

LAW 2016/17

Department of Law

Citizens and transatlantic free trade agreements:

How to reconcile American 'constitutional nationalism' with European 'multilevel constitutionalism'?

Ernst-Ulrich Petersmann 

European University Institute

Department of Law

Citizens and Transatlantic Free Trade Agreements:

HOW TO RECONCILE AMERICAN 'CONSTITUTIONAL

NATIONALISM' WITH EUROPEAN 'MULTILEVEL

CONSTITUTIONALISM'?

Ernst-Ulrich Petersmann

EUI Working Paper LAW 2016/17 
This text may be downloaded for personal research purposes only. Any additional reproduction for other purposes, whether in hard copy or electronically, requires the consent of the author. If cited or quoted, reference should be made to the full name of the author, the title, the working paper or other series, the year, and the publisher.

ISSN 1725-6739

(C) Ernst-Ulrich Petersmann, 2016

Printed in Italy

European University Institute

Badia Fiesolana

I-50014 San Domenico di Fiesole (FI)

Italy

www.eui.eu

cadmus.eui.eu 
Author contact details

\section{Ernst-Ulrich Petersmann}

Emeritus Professor of International and European Law European University Institute

Florence, Italy

Ulrich.Petersmann@eui.eu 


\begin{abstract}
The EU free trade agreements (FTAs) with Canada and the USA aim at protecting transnational public goods - like a rules-based, transatlantic market - that could be progressively extended to other European and North-American FTA member states and serve as a model for reforming also worldwide trade rules and governance institutions. As explained by democratic and cosmopolitan republicanism and 'law and economics', international law and governance can protect public goods more effectively and legitimately if citizens are empowered as 'democratic principals' and republican 'constituent powers' to hold multilevel governance institutions legally, democratically and judicially accountable for their frequent governance failures. The Lisbon Treaty established a 'cosmopolitan foreign policy constitution' requiring 'protection of its citizens', 'strict observance of international law' and rightsbased market regulations also in the EU's external relations (cf. Arts 3, 21 TEU). This contribution criticizes the EU policies of disempowering citizens in FTAs with constitutional democracies and undermining their fundamental rights and judicial remedies. Without stronger accountability to its citizens, the EU cannot address its crises of legitimacy and disregard for rule of law.
\end{abstract}

\title{
Keywords
}

constitutionalism; cosmopolitanism; free trade agreements; fundamental rights; republicanism 


\section{Table of contents}

INTRODUCTION: TRANSFORMATIVE TRANSATLANTIC FREE TRADE AGREEMENTS? .............................. 1

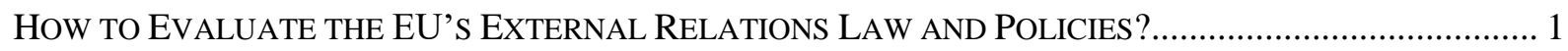

The EU's republican and cosmopolitan 'foreign policy constitution' limits the EU's foreign

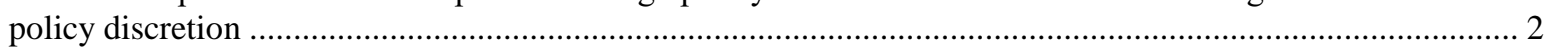

The EU must respect and defend legitimate 'constitutional pluralism' ................................................................ 3

'COSMOPOLITAN CONSTITUTIONALISM’ AND ITS LIMITS: THE EXAMPLE OF LEGAL AND JUDICIAL

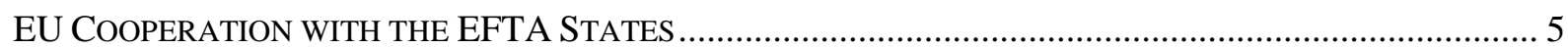

'Homogeneity obligations', judicial deference and 'contra-punctual integration law' in the EEA ..................... 6

Constitutional nationalism and its limits in the EU's FTAs with third countries ............................................. 8

‘TRANSFORMATIVE’ TRANSATLANTIC FTAS Without RightS AND REMEDIES OF CitizENS? ............ 9

Need for limiting 'governance failures' in transatlantic relations................................................................. 10

Legitimacy deficits of non-transparent CETA negotiations ................................................................... 12

Why CETA and TTIP risk undermining rights of citizens in transatlantic relations ...................................... 13

TRANSPARENT, DEMOCRATIC GOVERnANCE OF TRANSATLANTIC MARKET REGULATIONS? .............. 15

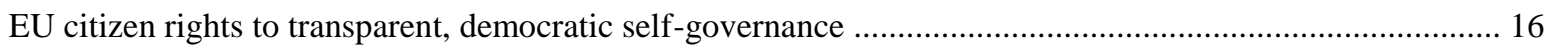

The EU Commission's 'transparency initiative' and 'cosmopolitan public reason' ........................................ 17

Democratic legitimacy of FTA negotiations, ratification and implementation? ................................................ 18

INVESTOR-STATE ARBITRATION RATHER THAN EQUAL RIGHTS OF CITIZENS TO EFFECTIVE

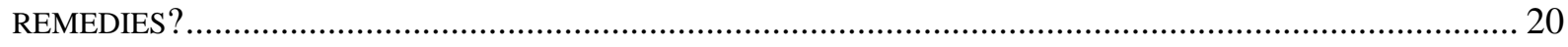

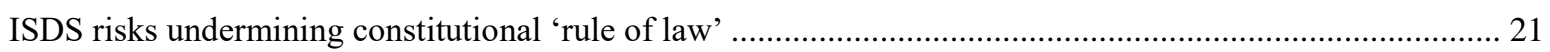

Multilevel judicial protection of equal rights and rule of law as a transnational PG ..................................... 22

CONCLUSION: DISFRANCHISEMENT OF CITIZENS UNDERMINES THE LEGITIMACY AND

EFFECTIVENESS OF MULTILEVEL GOVERNANCE OF TRANSNATIONAL PGS ........................................ 23 



\section{Introduction: Transformative transatlantic free trade agreements?}

Article 30.6 of the Canada-European Union (EU) Comprehensive Economic and Trade Agreement (CETA) provides that ' $(\mathrm{n})$ othing in this Agreement shall be construed as conferring rights or imposing obligations on persons other than those created between the Parties under public international law, nor as permitting this Agreement to be directly invoked in the domestic legal systems of the Parties'. Is this EU policy of explicitly excluding 'direct effects' of Free Trade Agreements (FTAs) - and of offering investor-state arbitration privileges only to foreign investors - compatible with its 'cosmopolitan foreign policy mandate' to contribute 'in its relations with the wider world ... to the protection of its citizens' and 'to the strict observance ... of international law' (Articles 3, 21 TEU)? Can the declared goal of 'transformative' transatlantic FTAs be realized by disfranchising citizens as 'democratic principals', main economic actors, and 'agents of justice', and by impeding their access to effective judicial remedies in domestic courts? Answers to these questions depend on the legal methodology and value premises for evaluating the EU and FTAs. This paper concludes that 'law and economics', 'comparative institutionalism', 'republican public goods (PGs) theories' for multilevel governance of transnational 'aggregate PGs' (like an undistorted transatlantic market), and 'constitutional theories' of multilevel governance argue for empowering citizens through legal, democratic and judicial remedies so as to limit - and hold accountable - the ubiquity of abuses of public and private powers in transnational markets. Just as rights and judicial remedies of citizens were of crucial importance in the creation of common markets in federal states (e.g. in Germany and Switzerland during the 19th century), in the EU as well as in the European Economic Area (EEA), so do 'comparative institutionalism', 'republicanism' and 'multilevel constitutionalism' argue for legally empowering citizens as 'constituent powers' that must hold all 'constituted, limited governance powers' accountable and, thereby, promote 'institutionalization of public reason', 'republican virtues' and 'democratic capabilities'. Arguably, CETA and the Transatlantic Trade and Investment Partnership (TTIP) could promote their economic and (geo)political objectives more effectively if - unlike the Trans-Pacific Partnership (TPP) and the Asian-led Regional Comprehensive Economic Partnership - they provide for citizen-driven 'cosmopolitan economic law' recognizing citizens as legal subjects entitled to enforce, e.g., competition, trade, environmental, consumer protection and social rules in domestic courts. A 'cosmopolitan network conception' of transatlantic FTAs is more supportive of the 'global supply chains' and other economic networks than state-centered 'Westphalian conceptions' dominated by governmental self-interests in limiting legal and democratic accountability of governments vis-à-vis citizens (e.g. during the 5 years of secretive CETA negotiations 2009-2014). As illustrated by European integration law, FTAs have legal importance far beyond utilitarian economics; they should be used by Europe and North-America for reforming the 'disconnected UN/WTO governance' dominated by government executives prioritizing their own rights and undermining transnational rule of law to the detriment of citizens, for instance by presenting UN and WTO commitments as 'breakable contracts between governments' that citizens and domestic courts should not be allowed to apply and rely on. As both American courts and the EU Court are reluctant to submit to transatlantic courts or investor-state arbitration, using domestic courts for protecting citizens against harmful effects of CETA and TTIP could set a globally important precedent for strengthening rule of law and legitimizing multilevel governance for the benefit of citizens.

\section{How to Evaluate the EU's External Relations Law and Policies?}

According to Article 21:1 of the 2007 Lisbon Treaty on European Union (TEU), the 'Union's action on the international scene shall be guided by the principles which have inspired its own creation, development and enlargement, and which it seeks to advance in the wider world: democracy, the rule of law, the universality and indivisibility of human rights and fundamental freedoms, respect for human dignity, the principles of equality and solidarity, and respect for the principles of the United Nations Charter and international law.' Article 3:5 TEU specifies this 'cosmopolitan foreign policy mandate' by 
requiring, inter alia, that '(i)n its relations with the wider world, the Union shall ... contribute to the protection of its citizens' and to 'strict observance and the development of international law'. The Court of Justice of the EU (CJEU) emphasizes that 'respect for human rights is a condition of the lawfulness of Community acts" ${ }^{1}$ also in the external relations of the EU; EU law (notably the EU Charter of Fundamental Rights $=$ EUCFR) protects fundamental rights as constitutional restraints on the exercise of all public authority by EU institutions. Hence, this contribution examines the EU negotiations on transatlantic FTAs from the perspective of EU constitutional law and the rights of EU citizens rather than from the different perspectives of trade politicians in NAFTA countries (e.g. focusing on utilitarian 'Kaldor-Hicks efficiency'). Can the objective of 'transformative transatlantic FTAs' be realized if - as provided for in Article 30.6 CETA - citizens have no rights and judicial remedies in domestic courts against violations of FTA rules? This contribution argues that - the more globalization transforms national PGs into transnational 'aggregate PGs' (like transatlantic and global markets, transnational rule of law) which no country can protect unilaterally without international law and institutions - the more the human right obligations of all UN member states and the republican and 'legislative functions' of international 'PGs treaties' require to interpret such treaties - at least inside a constitutionally limited Union of states, peoples and citizens like the EU - like democratic legislation for protecting the common good (res publica) of citizens as 'democratic principals' of all multilevel governance agents.

\section{The EU's republican and cosmopolitan 'foreign policy constitution' limits the EU's foreign policy discretion}

The EU rules and principles constituting, limiting, regulating and justifying the conferral of limited EU foreign policy powers (e.g. in Articles 3, 21 TEU, Articles 205 ff TFEU, the EUCFR) for multilevel protection of transnational PGs can be construed as a 'cosmopolitan foreign policy constitution' based, inter alia, on the following principles for the EU external relations policies:

1. The EU's 'multilevel rights constitutionalism' - as illustrated by the inclusion of 'human rights clauses' into more than $130 \mathrm{EU}$ agreements with third countries ${ }^{2}$ and the multilevel legal and judicial protection of rights of citizens inside the EU - has enhanced the legitimacy and effectiveness of EU Treaty commitments to 'protection of its citizens' and of their human and constitutional rights in the EU's external relations (cf. Articles 3, 21 TEU, Articles 15-17, 47 of the EUCFR).

2. The multilevel legal commitments to 'rule of law' (Article 2 TEU) and to effective judicial remedies at national levels of governance (cf. Article 47 EUCFR), European levels of governance (cf. Article 19 TEU) and beyond the EU in regional PGs treaties (e.g. by the European Court of Human Rights, the EFTA Court) and worldwide PGs treaties (e.g. by WTO dispute settlement bodies, the International Tribunal for the Law of the Sea) aim at 'strict observance of international law' (Article 3 TEU) - without delegation of EU powers to violate international treaties approved by parliaments for the benefit of EU citizens.

3. EU constitutional law provides for multilevel parliamentary, participatory and deliberative democracy in internal and external policy-making (cf. Articles 9-12 TEU), as illustrated by parliamentary co-decision powers (e.g. of the directly elected European Parliament) and individual rights that go far beyond the more limited parliamentary and democratic principles in

\footnotetext{
${ }^{1}$ Opinion 2/94, European Court Reports (ECR) 1996, I-1759, para.34. On the 'Kadi-jurisprudence' annulling 'smart sanctions' of the EU on grounds of human rights violations even though these sanctions were ordered by the UN Security Council against alleged terrorists, see: E.U.Petersmann, Multilevel Judicial Protection of 'Access to Justice' and the EU's Duty to Contribute to 'Strict Observance and Development of International Law', in: M.Avbelj/F.Fontanelli/ G.Martinico (eds), Kadi on Trial. A Multifaceted Analysis of the Kadi Trial (Routledge 2014), 187-217.

2 Cf. E.U.Petersmann, Integrating Human Rights into EU Trade Relations - The EU as a Global Role Model? in: T.Takacs/A.Ott/A.Dimopoulos (eds), Linking Trade and Non-Commercial Interests: The EU as a Global Role Model? (CLEER Working Paper 2013/4).
} 
other multilateral treaties; the European Parliament has used its powers also to reject international draft agreements negotiated by EU executives without adequate involvement of the European Parliament. ${ }^{3}$

4. EU membership in worldwide and regional organizations has led to the incorporation into EU law of related 'PGs treaties' (like the WTO Agreement, the UN Convention on the Law of the Sea, the UN Convention on Climate Change) as 'integrating parts of the Community legal system', thereby justifying legal presumptions that precise and unconditional treaty obligations of the EU (e.g. under the EEA and other free trade and association agreements) can be invoked by citizens also in domestic courts as relevant legal context; this judicial protection of individual rights (e.g. based on EU trade agreements with EFTA countries, Russia and Turkey) is, however, increasingly resisted by EU diplomats interested in limiting their legal and judicial accountability. ${ }^{4}$

The explicit 'foundation' (Article 2 TEU) of both the internal and external EU law - and the legal definition of 'the Union's aim' (Article 3 TEU) - in terms of protection of human rights, rule of law, democratic governance and specific PGs (like the common market, a monetary union) exclude pathdependent claims that the EU external relations law 'lacks a telos' and sets no specific goals limiting the EU's foreign policy discretion. ${ }^{5}$ For instance, EU constitutional law protects fundamental rights also in the external relations of the EU (e.g. 'the freedom to conduct a business in accordance with Union law' pursuant to Article 16 EUCFR) and permits limitations 'on the exercise of the rights and freedoms recognised by this Charter... only if they are necessary and genuinely meet objectives of general interest recognised by the Union or the need to protect the rights and freedoms of others' (Article 52 EUCFR). The EU's 'cosmopolitan' and 'republican constitutionalism' justifies not only legal and judicial review of foreign policy restrictions of rights and freedoms of citizens, as illustrated by the Kadi-jurisprudence. The establishment of a Union of states, peoples and citizens based on principles of conferral, subsidiarity and proportionality (cf. Article 5 TEU) also excludes claims that 'the EU's external policy objectives are non-teleological, non-prioritised, open-ended, and concerned more with policy orientation than goalsetting'. ${ }^{6}$

\section{The EU must respect and defend legitimate 'constitutional pluralism'}

Arguably, UN law and EU law proceed from similar 'principles' of human rights, democratic selfdetermination of peoples, state sovereignty and peaceful settlement of disputes based on transnational rule of law, as illustrated by the explicit reference in the Preamble of the European Convention on Human Rights (ECHR) to the 1948 Universal Declaration of Human Rights and by the incorporation of the fundamental freedoms guaranteed by the ECHR as 'general principles of the Union's law' (Article 6 TEU). ${ }^{7}$ The customary law requirement of interpreting treaties 'in conformity with the principles of justice', including also 'human rights and fundamental freedoms for all' - as recalled in the Preamble of the 1969 Vienna Convention on the Law of Treaties (VCLT) in view of the human rights obligations of all UN member states and the general 'principles of justice' recognized in UN law as well as in

3 Cf. M. Cremona, International Regulatory Policy and Democratic Accountability: The EU and the ACTA, in: M.Cremona/P.Hilpold/N.Lavranos/S.Schneider/A.Ziegler (eds), Reflections on the Constitutionalisation of International Economic Law - Liber Amicorum for Ernst-Ulrich Petersmann (Nijhoff 2014), at $155 \mathrm{ff}$.

${ }^{4}$ Cf. A.Semertzi, The Preclusion of Direct Effect in the Recently Concluded EU Free Trade Agreements, in: CMLRev 51 (2014), 1125-1158.

5 The 'absence of a telos' and 'open-ended characteristics' in EU external policies are emphasized notably by Anglo-Saxon lawyers like M.Cremona, A Reticent Court? Policy Objectives and the Court of Justice, in : M.Cremona/A.Thies (eds), The European Court of Justice and External Relations Law. Constitutional Challenges (Hart 2014), at 29, 31.

${ }^{6}$ M.Cremona (note 5)

${ }^{7}$ Cf. E.U.Petersmann, Multilevel Constitutionalism for Multilevel Governance of Public Goods: Methodology Problems in International Law (Hart 2016), chapter I.1. 
national Constitutions - requires to examine to what extent person-centered 'constitutional interpretations' and judicial clarifications of EU law (e.g. in terms of recognizing citizens as legal subjects, protecting their fundamental rights, limiting delegation of governance powers through common constitutional principles) should guide also interpretations of other fields of international law like FTAs among constitutional democracies. The 'human rights imperative' of recognizing citizens as 'constituent powers', 'democratic principals' and 'agents of justice' (e.g. entitled to individual 'access to justice' and democratic self-governance) justifies not only the 'cosmopolitan foreign policy constitution' in the Lisbon Treaty and its mandate to extend human rights, democratic governance and rule of law (i.e. the 'trias' of constitutional democracies and also of EU constitutional law) in the external relations of the EU. Arguably, the EU's 'cosmopolitan foreign policy constitution' has also been most successful in those foreign policy areas where - as in the successive EU enlargements to now 28 EU member states and in the EU's 'neighborhood policies' vis-à-vis the EFTA countries and central European countries the EU's 'constitutional design' of international treaties transformed centuries of power politics among European countries into multilevel republican and cosmopolitan constitutionalism protecting peaceful cooperation among citizens across national frontiers. Also UN human rights law requires 'embedding' governance of transnational PGs into domestic constitutional laws in order to hold multilevel governance of PGs legally, democratically and judicially more accountable in terms of democratic, republican and cosmopolitan constitutionalism. ${ }^{8}$ Yet, as human rights also protect individual and democratic diversity and are not effectively implemented in UN law and governance, the reality of 'constitutional pluralism' protects the sovereign freedom of constitutional democracies (e.g. in the NAFTA countries) to design their external relations in conformity with their different constitutional traditions.

The EU's international agreements respond to such diverse constitutional and legal contexts in third countries by actively promoting transnational 'constitutional pluralism' (see below section II), for instance through (1) extending the EU's 'multilevel constitutional democracy' to accession countries; (2) providing for multilevel protection of cosmopolitan rights and judicial remedies in the EEA Agreement with EFTA states; and (3) concluding more decentralized FTAs (e.g. with Switzerland), customs union agreements (e.g. with Turkey) and association agreements (e.g. with other neighboring countries) if the third country is either unwilling (like Switzerland) or incapable of accepting the EU's multilevel constitutionalism (acquis communautaire). Sections III-VI of this contribution criticize the CETA and TTIP negotiations of the EU for disregarding the EU's 'cosmopolitan foreign policy constitution' and for unnecessarily undermining rights and judicial remedies of citizens in transatlantic market regulations. As discussed below, already prior to the CETA and TTIP negotiations, the EU's 'foreign policy constitution' had not prevented 'governance failures' of EU institutions, such as

- - EU non-compliance with 'strict observance of international law' (contrary to Article 3 TEU) and with the prohibition of 'disproportionate' restrictions of fundamental rights (e.g. through illegal and welfare-reducing market restrictions persistently violating the EU's WTO obligations and the 'freedom to conduct a business in accordance with Union law', cf. Article 16 EUCFR);

- - power-oriented refusal by European courts to protect EU citizens and their 'right to an effective remedy' (Article 47 EUCFR) against arbitrary EU violations of international treaty obligations;

- - authoritarian 'disempowerment' of EU citizens by EU institutions excluding individual rights and judicial remedies in international trade and investment agreements - contrary to the requirement of 'protection of its citizens' in EU external relations (Article 3 TEU) and of placing 'individuals at the heart of its activities' (Preamble EUCFR);

- - non-transparent and non-inclusive 'executive dominance' in many EU foreign policy areas contrary to the requirement in Article $10 \mathrm{TEU}$ of taking decisions 'as openly and as closely as possible to the citizen'; and

${ }^{8}$ Cf. Petersmann (note 7), chapter I.3. 
- - inadequate parliamentary and democratic participation in, and control of, EU negotiations on international 'PGs treaties' (e.g. during the secretive CETA negotiations from 2009 to 2014 and the preceding FTA negotiations with Korea and other trading partners). ${ }^{9}$ The fiscal, debt, economic growth, migration and rule of law crises in some EU member states reflect not only national governance failures (e.g. to respect the agreed EU fiscal, debt and economic convergence disciplines) ${ }^{10}$ but also EU governance failures in protecting 'rule of law' (e.g. compliance with the EU's fiscal and debt disciplines, the Schengen and Dublin rules on treatment of immigrants and refugees at the EU's external borders) throughout the EU.

Contrary to claims that economic globalization and international legal restraints on national policy autonomy are inconsistent with national democratic autonomy ${ }^{11}$, democratic approval of, and compliance with international 'PGs treaties' can strengthen and enhance 'individual' and 'democratic self-government' and social welfare of citizens in a globally interdependent world, for instance by protecting rule of law and sovereign powers to regulate PGs across national borders and limiting harmful practices of other states. ${ }^{12}$ As discussed in the following section II, the 1992 EEA Agreement between EU and EFTA member states illustrates how the EU's republican and 'constitutional foreign policy objectives' can be effectively promoted also in external relations with third countries even if their peoples insist on maintaining their different constitutional traditions.

\section{'Cosmopolitan Constitutionalism' and its Limits: The Example of Legal and Judicial EU Cooperation with the EFTA States}

European integration law illustrates a diversity of successful methods for progressively reconciling the legitimate reality of 'constitutional pluralism' in international cooperation among constitutional democracies with diverse constitutional traditions, such as

1. the 'multilevel constitutional democracy approach' underlying the progressive extension of EU law to the more than 20 European countries which acceded to the European Community since the 1970s: the EU 'provisions on democratic principles' (Articles 9-12 TEU) indicate that the EU derives democratic legitimacy not only indirectly from the consent to EU law by democratically elected, national and EU governance institutions (including the directly elected European Parliament), but also directly from EU citizenship, from protection of the constitutional rights of EU citizens, their democratic participation and deliberation in the democratic governance of the EU;

2. the 'cosmopolitan foreign policy approach'13 underlying the extension of the EU's constitutional rights and judicial remedies of citizens to the EFTA countries focuses on multilevel constitutional, democratic and judicial protection of cosmopolitan rights in the context of the 'two pillars system' of the EEA (see below); unlike multilevel constitutional democracy inside

\footnotetext{
${ }^{9}$ On this 'Lockean dilemma' of inadequate constitutional control of discretionary foreign policy powers see: P.Hilpold, The 'Politicization' of the EU's Common Commercial Policy - Approaching the 'Post-Lockean' Era, in : Cremona et alii (note 3), 21-36.

${ }^{10}$ Cf. C. Bastasin, Saving Europe. How National Politics Nearly Destroyed the Euro (Brookings Institution Press 2012).

${ }^{11}$ Cf. D.Rodrik, The Globalization Paradox: Democracy and the Future of the World Economy (Norton 2011).

${ }^{12}$ On the need for justifying international guarantees of freedom, non-discrimination, rule of law and protection of other PGs in terms of their contribution to corresponding legal guarantees in domestic constitutional systems, and their promotion of mutual synergies in terms of transnational aggregate PGs for the benefit of citizens with due respect for legitimate 'constitutional pluralism', see: E.U.Petersmann, Constitutional Functions and Constitutional Problems of International Economic Law. International and Domestic Foreign Trade Law and Policy in the United States, the European Community and Switzerland (Fribourg University Press 1991).

${ }^{13}$ On the need for transforming international into cosmopolitan communities based on human and democratic rights and responsibilities see also: J.Habermas, The Crisis of the European Union. A Response (Polity Press, 2012), at $53 \mathrm{ff}$.
} 
the EU, the more deferential EEA model focuses on representative democracy at the level of EFTA member states, deliberative democratic justification of EEA law-making (e.g. the incorporation of EU 'secondary law' into EEA law by the EEA institutions), and on multilevel judicial protection of common market rights, constitutional rights of citizens and 'homogeneity' between EU and EEA law through the EFTA Court and national courts in EFTA member states;

3. the 'national constitutional democracy approaches' underlying the EU's bilateral FTAs (e.g. with Switzerland) and customs union agreements (e.g. with Turkey) protect cosmopolitan rights and judicial remedies in the context of bilateral economic agreements that can be invoked by citizens in domestic and European courts;

4. the 'executive intergovernmentalism' characteristic of the EU's 'new FTAs' since 2006, by contrast, explicitly excludes rights and effective judicial remedies of citizens and circumvents effective parliamentary and judicial control of governmental regulations and violations of international law; this approach dominates also the transatlantic FTAs with NAFTA states in response to the 'legal dualism' and 'constitutional nationalism' in many countries outside Europe; for instance, 'hegemonic power politics' often induces the US Congress to assert its constitutional power to ignore international treaty obligations inside the USA on the ground that majoritarian democratic self-governance - even if driven by 'Congressional interest group politics' ignoring democratic demand for transnational PGs - should take priority inside US law (based on the 'later-in time' rule regarding US legislation) over multilevel protection of transnational rule of law and of other international PGs. The TTIP negotiations raise the question of how such 'constitutional nationalism' can be reconciled with the EU's multilevel constitutionalism so as to protect transnational 'aggregate PGs' (like a rules-based transatlantic market enhancing general consumer welfare) for the benefit of EU citizens.

\section{'Homogeneity obligations', judicial deference and 'contra-punctual integration law' in the EEA}

The EEA Agreement was concluded on 2 May 1992 between the EC and its member states on the one hand and the EFTA states; it extends free movement of goods, services, persons and capital to the EEA/EFTA states (Iceland, Liechtenstein, Norway - Switzerland did not ratify the EEA Agreement following a negative popular referendum) ${ }^{14}$ EEA law and its EFTA Court protect fair conditions of competition and abolish discrimination on grounds of nationality in EEA member states. The successful operation of the EEA relies on a two-pillar system of supervision (involving the European Commission, the EFTA Surveillance Authority and national authorities) and of judicial control (involving the CJEU, the EFTA Court and national courts). As EU and EEA law constitute separate legal orders and the 'EEA law on the books' includes numerous indeterminate provisions, Article 6 EEA prescribes the following 'homogeneity obligations':

\footnotetext{
'Without prejudice to future development of case law, the provisions of this Agreement, in so far as they are identical in substance to corresponding rules of the Treaty establishing the European Economic Community and the Treaty establishing the European Coal and Steel Community and to acts adopted in application of these two Treaties, shall, in their implementation and application, be interpreted in conformity with the relevant rulings of the Court of Justice of the European Communities given prior to the date of signature of this Agreement.'
}

Article 3:2 of the 1992 Agreement among the EFTA states on the establishment of a Surveillance Authority and the EFTA Court of Justice adds the following, additional homogeneity obligation:

\footnotetext{
${ }^{14}$ For a survey of EEA law see : E.Mendez Pinedo, EC and EEA Law. A comparative study of the effectiveness of European law (Europa Law Publishing 2009); C.Baudenbacher, The EFTA Court in Action (German Law Publishers 2010); The EEA and the EFTA Court. Decentered integration (edited by the EFTA Court, Hart 2014).
} 
'In the interpretation and application of the EEA Agreement and this Agreement, the EFTA Surveillance Authority and the EFTA Court shall pay due account to the principles laid down by the relevant rulings by the Court of Justice of the European Communities given after the date of signature of the EEA Agreement and which concern the interpretation of that Agreement of of such rules of the Treaty establishing (the EEC and the ECSC) ... in so far as they are identical in substance to the provisions of the EEA Agreement'...

In view of the different (e.g. more 'dualist') constitutional traditions of EFTA states and their limited influence on EU legislation that becomes binding the EFTA states through EEA law (e.g. due to incorporation of EU rules into EEA law by the EEA Joint Committee) and its judicial clarification by the EFTA Court, the EEA objectives of legislative, judicial and institutional homogeneity - and the legal relationships between EEA law and the national legal systems in EFTA countries - were interpreted and developed by EEA member states and the EFTA Court in more deferential and 'pluralist' ways compared to the EU constitutional principles of 'legal primacy', 'direct effect' and 'direct applicability' by individuals of precise and unconditional EU rules. For instance, even the EFTA Court characterized EEA law as a 'distinct legal order', and some legal scholars advocated to interpret the EEA law in conformity with the EU principles of legal primacy and direct effect so as to realize the 'legal homogeneity' obligations and protect rights of private market actors; the main legal doctrines elaborated by the EFTA Court - in close legal and judicial dialogues with EEA member governments, national courts and EU institutions - acknowledged, however, lack of supranational primacy and of direct effect of EEA law. All EEA governments recognized the more deferential 'judge-made principles' of 'quasiprimacy' and 'indirect effect' of implemented EEA rules inside national legal systems, consistent interpretation requirements, state liability and principles of loyalty, as they were progressively developed in the jurisprudence of the EFTA Court and its 'judicial dialogues' with national courts and governments in EEA member states. As a result of these 'multilevel constitutional dialogues' over a period of more than 20 years of EEA legal practices, conflicts between EU law and EEA law were successfully avoided. ${ }^{15}$ The dynamically emerging 'cosmopolitan constitutionalism' in the multilevel governance among the 31 EEA member states revealed how 'the classical dualist paradigm appears to be increasingly inadequate - descriptively as well as normatively - to explain how the EEA Agreement, an international treaty sui generis comprising its own specific legal order, fits into domestic practice'. ${ }^{16}$ Even though national governments and courts initially advocated 'nationalist approaches' for interpreting EEA law, the EEA's institutionalization of multilevel legal and judicial dialogues among national, EEA and EU institutions regarding the interpretation and progressive development of EEA law emphasized the need for protecting rights and judicial remedies of EEA citizens with due respect for 'constitutional pluralism' and 'contra-punctual legal techniques' as explained by EU Advocate-General Maduro: 'The discovery that different melodies could be heard at the same time in a harmonious way was one of the greatest developments in musical history and greatly enhanced the art and pleasure of music. In law too, we have to learn how to manage the non-hierarchical relationship between different legal orders and institutions and to discover how to gain from the diversity and choices that are offered to us without generating conflicts that ultimately will destroy those legal orders and the values they sustain. ${ }^{17}$

Similarly, the 'consistent interpretation' requirements of customary international law require interpreting 'overlapping PGs treaties' (like FTAs and EU law) in mutually consistent ways with due

\footnotetext{
${ }^{15}$ But such conflicts remain possible in the very rare cases where a national act of parliament asserts legal primacy vis-à-vis international obligations based on the constitutional doctrine of lex posterior legi priori derogat; cf. O.I.Hannesson, Giving Effect to EEA Law - Examining and Rethinking the Role and Relationship between the EFTA Court and the Icelandic National Courts in the EEA Legal Order, Florence: EUI doctoral thesis September 2012, chapter 6.

${ }^{16}$ O.I.Hannesson, Legal Pluralism in the EEA Legal Order: The EFTA Court's Role in a Broader Institutional Context, in: Cremona et alii (note 3), at 81-95, at 81 .

17 M.P.Maduro, Contrapunctual Law: Europe's Constitutional Pluralism in Action, in : N.Walker (ed), Sovereignty in Transition (Hart 2003), 501-537, at $524 \mathrm{f}$.
} 
respect for their diverse 'principles of justice' and legitimately diverse constitutional traditions. In multilevel judicial cooperation and interpretation of multilevel regulation of transnational 'aggregate PGs', national and international judges must cooperate - like musicians inside an orchestra - in discovering the most harmonious ways of 'orchestrating PGs', especially if there is no single conductor of the orchestra. The common human rights obligations of constitutional democracies require multilevel legal and judicial protection and clarification of rights and remedies of citizens by 'balancing' - in the context of 'contra-punctual legal interpretations' and 'democratic discourse justifications'- the rights and other constitutional principles of the legal systems involved with due respect for legitimate 'constitutional pluralism', i.e. that no single legal system can legitimately impose its own constitutional traditions and prescribe a 'single voice' for the law in disregard for the many dissonances among diverse jurisdictions, peoples and citizens in multilevel governance of transnational aggregate PGs. ${ }^{18}$

\section{Constitutional nationalism and its limits in the EU's FTAs with third countries}

The 'constitutional pluralism' underlying the EEA legal order reflects the need for reconciling the 'homogeneity obligations' of EFTA states vis-à-vis the EU legal order with the constitutional task of protecting legal coherence inside the EEA legal order through democratic and judicial justifications of transnational rule of law in the common market among all 31 EEA member states. National courts, the CJEU and the EFTA Court interpret EEA law from the diverse perspectives of their national, EU and EFTA jurisdictions. Their judicial independence and mutual duties of 'judicial comity' induce the courts to cooperate in clarifying common constitutional principles and adjusting their diverse national, EU and EEA legal doctrines (e.g. by rejecting the EU doctrine of 'direct effect' in the different context of the EEA legal system so as to accommodate the 'dualist constitutional traditions' in the Nordic EFTA states).

Vis-à-vis constitutional democracies (like Switzerland) whose populations rejected joining the EEA, the EU has responded by concluding bilateral FTAs that reconcile EU law with Swiss law, respect legitimate 'constitutional pluralism' in Switzerland, and adjust the EU-Switzerland FTA to the dynamically evolving EU secondary law. If third trading partners of the EU do not accept the jurisdiction of the CJEU (e.g. as provided for in the EU-Turkey association agreement) or of the EFTA Court for the settlement of disputes (e.g. over the interpretation of the EU-Switzerland FTA), the EU must protect its constitutional principles unilaterally and - if necessary - condition the opening of its common market to third countries on 'legal homogeneity obligations' (e.g. as provided for in the bilateral EU-Switzerland agreements). Also the transatlantic FTAs go far beyond economic bargaining by acknowledging common constitutional principles like human rights, transnational rule of law and democratic governance in transatlantic relations. Their treaty objectives to promote a permanent framework for regulatory cooperation and harmonize economic and non-economic regulations through common rules - even if fundamentally different from the EEA objectives of extending the EU's common market regulations to third trading partners - do not change the legislative procedures in EU and NAFTA countries. Nonetheless, they require 'constructing a We' ${ }^{19}$ so as to justify collective rule-making (e.g. reciprocal recognition of production standards) and reciprocal protection of rule of law. How can - and should - the 'constitutional nationalism' in the USA be reconciled with the EU's multilevel constitutionalism? As the world's largest exporter and importer of goods and services taken together, the largest foreign direct investor and the most important destination for foreign direct investments: to what extent must EU diplomats use the 'civilian power' of the EU in order to meet their legal obligations to 'uphold and promote' respect for human rights, democracy and rule of law in internal and external EU law on multilevel governance of PGs (cf. Articles 3 and 21 TEU)?

\footnotetext{
${ }^{18}$ Cf. Hannesson (note 16); see also N.Lavranos, The Systemic Responsibility of the ECJ for Judicial Comity towards International Courts and Tribunals, in: Cremona et alii (note 3), 51-64.

${ }^{19}$ Cf. P.Lomba, Constructing a 'We': Collective Agency and the European Union, in: Cremona et alii (note 3), at 97-110.
} 


\section{'Transformative' Transatlantic FTAs without Rights and Remedies of Citizens?}

In 2006, the lack of progress in the Doha Round negotiations prompted the EU to launch a new 'Global Europe' trade and investment strategy aimed at concluding 'deep and comprehensive' FTAs with economically and strategically important partner countries in Asia (e.g. Korea, Singapore and Vietnam) and in the Americas. The CETA and TTIP negotiations were launched on the promise to elaborate 'transformative FTAs' that - similar to other mega-regional FTAs like the TPP agreement signed in February 2016 among 12 pacific trading countries producing more than $40 \%$ of global GDP ${ }^{20}$ - would liberalize and regulate trade in goods and services far beyond WTO rules; it pursues 'geo-political importance' by setting new standards for multilateral trade, investment, environmental, labor and regulation. TTIP focuses on the following four objectives that are progressively clarified in 24 joint EUUS working groups on TTIP, which aim at finalizing a draft agreement before the end of $2016^{21}$ :

1. Ambitious, reciprocal liberalization of market access for goods, services, investments and public procurement at all levels of government; market access for goods and services aims at removing customs duties on goods and restrictions on services, gaining better access to public markets, and making it easier to invest; the exclusion of audio-visual services, of general free movement of workers and of other citizens illustrates that TTIP remains less ambitious than the EEA agreement.

2. Reducing non-tariff trade barriers and enhancing the compatibility of regulatory regimes through a permanent system of regulatory cooperation; improved regulatory coherence and cooperation in dismantling unnecessary regulatory barriers (e.g. due to bureaucratic duplication of procedures) will go beyond the WTO Agreements on Technical Barriers to Trade (TBT) and Sanitary and Phytosanitary Measures (SPS), for instance by means of specific sectorial agreements for textiles, chemicals, pharmaceuticals, cosmetics, medical devices, cars, electronics/ICT, machinery/engineering and pesticides.

3. Developing common rules (e.g. for consumer, labour, investment, social and environmental protection, civil society involvement, parliamentary cooperation) to address shared, global trade challenges; the improved international cooperation in setting international standards (e.g. for energy and raw materials, labour and environment, trade and sustainable development, public procurement, intellectual property, competition policy, small and medium-sized enterprise, trade remedies, customs and trade facilitation) aims at making TTIP countries global 'standard-setters' rather than 'standard-takers'.

4. Institutional structures for progressively implementing the TTIP; while the proposed dispute settlement provisions remain less ambitious than the EEA agreement (e.g. its EFTA Court), the TTIP Regulatory Council could introduce innovative procedures for harmonisation, mutual recognition agreements and common minimum (equivalence) standards aimed at making TTIP a 'standard-setter' also for third countries exporting to TTIP countries and complying with TTIP standards.

Evaluations of CETA and TTIP depend on their respective legal, economic and political methodologies for multilevel governance of PGs like a transatlantic market that could - in future - include all 3 NAFTA states, the 31 EEA member states and additional states (like Switzerland and Turkey). From utilitarian economic perspectives, transatlantic FTAs offer important economic welfare gains, for instance in terms of reducing the costs of production, trade and consumption and enhancing competitiveness of European industries and consumer welfare. They also offer geopolitical gains, e.g. in terms of

- promoting energy security in Europe;

\footnotetext{
${ }^{20}$ They include Australia, Brunei Darussalam, Canada, Chile, Japan, Malaysia, Mexico, New Zealand, Peru, Singapore, USA and Vietnam.

${ }^{21}$ All following informations on the TTIP negotiations are based on information available on the website of the European Commission, Directorate-General for Trade: http://trade.ec.europa.eu/doclib/press.
} 
- setting global standards for regulation of the 'interface' between economic and non-economic PGs (like health protection, climate change prevention); and for

- facilitating future reforms of WTO law, for instance by preparing a later 'multilateralization' of mega-regional FTAs which could ultimately replace the ineffective WTO system for consensusbased, global trade liberalization by a more ambitious 'WTO II legal system' (similar to the replacement of GATT 1947 by the WTO Agreement).

Yet, economic integration gains, their social distribution and the democratic acceptability of legal reforms will depend largely on persuading and empowering citizens to cooperate in multilevel protection of transnational rule of law so that citizens can challenge, for instance, the long-standing market failures and governance failures in transatlantic relations which gave rise to numerous transatlantic economic disputes over the past decades. ${ }^{22}$ From the point of view of the EU's 'cosmopolitan foreign policy constitution' (cf. section I above) and of the successful 'cosmopolitan constitutionalism' in the EU's external relations with EFTA states (cf. section II), the EU's FTA negotiations with NAFTA countries continue to be distorted by democratic and 'republican governance failures' that risk undermining the constitutional rights of EU citizens, as illustrated by

- the intergovernmental exclusion of rights and effective judicial remedies of citizens (e.g. in Article 14.16 CETA);

- the lack of transparency and parliamentary control of the EU negotiations of CETA and of previous FTAs (see below section IV);

- the provision of arbitration privileges to foreign investors and related 'negative discrimination' against EU citizens in transatlantic economic cooperation (see below section V); and

- the intergovernmental disregard for the EU guarantees of rule of law (see below section VI), as illustrated by the US criticism that EU proposals of authorizing EU member states to restrict genetically modified organisms (GMOs) without scientific evidence of their potential health run counter to WTO law and to the need to promote global food security, scientific progress and 'public reason' in conformity with transatlantic rule of law.

\section{Need for limiting 'governance failures' in transatlantic relations}

Civil society struggles for collective protection of PGs have been documented in Europe since the ancient democratic Constitution of Athens and the republican Constitution of Rome 2500 years ago. Their historical lesson is that democratic protection of PGs depends on constitutional protection of democratic, republican and cosmopolitan rights and institutions enabling citizens to hold governance agents accountable for abuses of power. ${ }^{23}$ Comparative legal and institutional research confirms that the inadequate 'democratic input legitimacy' in transatlantic rule-making (as emphasized by 'stop TTIP' initiatives and by members of national and European parliaments), inadequate 'democratic output legitimacy' (e.g. in terms of undermining equal rights and remedies of EU citizens), and inadequate protection of transatlantic PGs (like rule of law) is due to the power-oriented 'executive dominance' of transatlantic relations that remain inadequately 'constitutionalized' for the benefit of citizens. The systemic 'governance failures' in the 'Transatlantic Partnership' since the 1990s were illustrated by transatlantic economic and legal disputes over EU import restrictions on bananas, safeguard measures, antidumping and countervailing duties, industrial subsidies (e.g. for US 'foreign sales corporations'), European agricultural subsidies, EU import restrictions on hormone-fed beef and GMOs, technical barriers to trade (e.g. on 'hushkits' for US airplanes), unilateral extraterritorial application of competition laws, US interferences with transatlantic data protection, discriminatory US practices in fields like government procurement and intellectual property rights, and inadequate, regulatory

\footnotetext{
${ }^{22}$ Cf. E.U.Petersmann/M.Pollack (eds), Transatlantic Economic Disputes. The EU, the US and the WTO (OUP 2003).

${ }^{23}$ Cf. Petersmann (note 7).
} 
cooperation in environmental policies, telecommunications, shipping- and air-transports. ${ }^{24}$ Many of these disputes confirmed R. Kagan's claim that - with regard to international law and policy cooperation - 'Americans are from Mars and Europeans are from Venus'. ${ }^{25}$ For instance, the 'constitutional nationalism' and hegemonic power politics cultivated by US politicians favors 'legal dualism' and US skepticism towards international law (e.g. prompting the US Congress to exclude rights of citizens to invoke and enforce international treaty obligations in US courts even if the US government accepted 'direct applicability' of such treaty obligations in domestic courts, e.g. pursuant to Article XX Government Procurement Agreement). European integration is built on greater trust in international law and in multilevel governance of international PGs (like multilevel legal and judicial protection of fundamental rights, transnational rule of law, common markets and competition law systems). American and European approaches to international economic governance often differ, as illustrated by the comparatively lesser participation of US regulatory agencies in international standard-setting organizations and US reluctance to ratify international human rights, labor law, criminal law and environmental conventions. The stronger US preferences for science-based risk assessment procedures (as internationally agreed in the WTO Agreement on SPS Measures) are linked to the comparatively stronger parliamentary control of US regulatory agencies and their avoidance of some of the health and SPS crises (like mad cow diseases) that undermined consumer confidence in Europe regarding sciencebased risk assessments of product and production standards. ${ }^{26}$

The EU Treaty requires (e.g. in Articles 3 and 21 TEU) to base external FTAs on the constitutional 'values' and 'principles' that successfully govern market regulation and competition throughout Europe. This rights- and citizens-based 'constitutional mandate' reflects the insight that - the more international treaties assume legislative functions for protecting transnational PGs which no single state can unilaterally protect without international law and institutions - the more must domestic institutions apply and protect international treaties approved by national parliaments for the benefit of citizens. Inside the EU and the EEA, citizens invoking and enforcing their rights in domestic jurisdictions - as 'market citizens' (e.g. producers, investors, traders, consumers), 'social citizens' (e.g. family members of workers moving across the EU), 'democratic principals' of multilevel governance agents (e.g. electing the European Parliament) and 'agents of justice' entitled to challenge abuses of public and private powers in national and European courts - have been among the most important 'drivers' for democratic acceptance, progressive development and decentralized enforcement of economic integration law, as reflected in the case-law of European Courts on individual rights under EU law. ${ }^{27}$ The multilevel judicial protection by national and European courts of the economic and constitutional rights of private plaintiffs against violations of EU law - as in the leading EU case-law triggered by complaints from the Dutch transporter Van Gend en Loos, the Italian lawyer Costa, the German vine grower Hauser, or the Belgian stewardess Defrenne - illustrated how constitutional rights and judicial remedies empower citizens to use their 'republican virtues' 28 for protecting multilevel compliance with treaties approved by parliaments for the benefit of citizens. Similar disputes are bound to arise also in future transatlantic

\footnotetext{
${ }^{24} \mathrm{Cf}$. the numerous case-studies and cross-sectoral studies in: Petersmann/Pollack (note 22).

${ }^{25}$ Cf. R.Kagan, Of Paradise and Power: America and Europe in the New World Order (Knopf 2003), at 3.

26 Cf. the numerous case-studies on American and European approaches to multilevel economic governance in: C.Joerges/E.U.Petersmann (eds), Constitutionalism, Multilevel Trade Governance and International Economic Law (Hart 2011).

${ }^{27}$ Cf. H. van Eijken, Citizenship and the Constitutionalization of the EU (Europa Law Publishing 2016).

${ }^{28}$ Cf. J.G.A.Pocock, The Machivallian Moment: Florentine Political Thought and the Atlantic Republican Tradition (Princeton UP 1975, emphasizing, e.g. on page 67, that the republican ideal of cultivating and exercising the four 'cardinal virtues' prudence, justice, courage and temperance - for citizenship as a public office remains central to the collective supply of PGs as explained by Aristotle and Cicero). On the diverse legal traditions of republicanism and the disagreement on whether the core values of republicanism should be defined in terms of liberty (non-domination), republican virtues of active citizenry finding self-realization in political participation and collective supply of PGs, communitarianism, social and political equality, or deliberative democracy, see: S.Besson/J.Luis Marti (eds), Legal Republicanism: National and International Perspectives (OUP 2009).
} 
relations - also beyond international movements of goods, services and investments, as illustrated by the EU-US disputes over data protection and by the expansion of EU citizenship rights in the EU 'area of freedom, security and justice' (Articles 67-89 TFEU).

EU citizenship implies 'republican duties' that call for effective judicial remedies by domestic courts of justice - rather than only by inter-state or investor-state arbitration without effective constitutional restraints - so as to protect democratic 'compliance constituencies' and transnational rule of law for the benefit of all citizens. ${ }^{29}$ Inside the EEA, the fundamental rights of EU citizens as codified in the EUCFR - such as 'freedom to conduct a business in accordance with Union law' (Article 16) and the 'right to an effective remedy and to a fair trial' (Article 47) - have empowered citizens to rely on 'strict observance of international law' (Article 3 TEU) across national boundaries. The 'emancipatory function' of FTAs among democracies - e.g. for extending multilevel protection of equal rights of citizens against abuses of foreign policy powers - was unduly neglected in the secretive CETA negotiations from 2009 to 2014. The increasing protests against TTIP illustrate that civil society and parliaments begin to resist 'disconnected intergovernmentalism'; international treaties with 'legislative functions' for protecting transnational PGs must be governed democratically and protect transnational rights and remedies of citizens so as to enable the 'democratic principals' to hold governance agents and their limited 'constituted powers' more accountable for the ubiquity of 'market failures' and 'governance failures' that continue to distort transatlantic relations, rule of law and consumer welfare. ${ }^{30}$

\section{Legitimacy deficits of non-transparent CETA negotiations}

In constitutional democracies, citizens are entitled to justification of law and governance on

- deontological grounds, for instance in terms of protection of equal freedoms as 'first principle of justice' (as explained in theories of justice from Kant to Rawls) and democratic 'discourse justifications' inducing reasonable citizens to accept legal rules as 'just' (e.g. justified by procedural and substantive reasons that citizens cannot reasonably reject);

- consequentialist 'republican grounds', like promotion of general consumer welfare through open markets, non-discriminatory conditions of competition and rule of law; and also

- on grounds of 'virtue ethics': successful democracies depend on the institutionalization of 'public reason' based on the virtues and struggles of citizens, 'civil servants' and parliamentarians to transform agreed 'principles of justice' (e.g. in EU and US constitutional law) into democratic legislation, judicial administration of justice and multilevel protection of PGs.

Such republican conceptions of multilevel governance of PGs - as being dependent on a 'démocratie de tous les jours' struggling for protection of 'aggregate PGs' demanded by citizens - seemed to be absent during the 5 years of secretive CETA negotiations. EU citizens following the occasional press conferences on these negotiations were amazed by the discrepancy between the EU 'law in the books' and the 'law in action'. According to EU law,

- 'decisions are taken as openly as possible and as closely as possible to the citizen' (Article 1 TEU); the 'institutions shall, by appropriate means, give citizens and representative associations the opportunity to make known and publicly exchange their views in all areas of Union action' (Article

\footnotetext{
${ }^{29}$ The need for limiting power-oriented foreign policies (e.g. perceiving international treaties as breakable contracts between governments rather than as instruments for protecting transnational rule of law for the benefit of citizens) by stronger ruleof-law institutions reducing transaction costs and protecting equal rights of citizens and other transnational PGs is also increasingly recognized by American academics; cf. K.Alter, The New Terrain of International Law: Courts, Politics, Rights, (Princeton UP 2014). Stronger judicial remedies can empower 'compliance supporters' (notably civil society actors) and 'compliance partners' (e.g. domestic and international institutions) to pressure governments to comply with treaty obligations ratified by parliaments for protecting transnational PGs for the benefit of citizens.

${ }^{30}$ Cf. D.Cardoso/P.Mtembu/M.Venhaus/M.Verde Garrido (eds), The Transatlantic Colossus. Global Contributions to Broaden the Debate on the EU-US Free Trade Area (Bertelsmann e-book 2015).
} 
11:1 TEU). Yet, the CETA was negotiated in almost complete secrecy. Following the publication of the draft text in September 2014, EU Trade Commissioner de Gucht responded to criticism from parliaments and civil society by rejecting renegotiation of the treaty provisions on investorstate arbitration as being 'now too late'.

- 'In its relations with the wider world, the Union shall ... contribute to the protection of its citizens' (Article 3:5 TEU). For, according to the EUCFR, the EU 'places the individual at the heart of its activities' (Preamble). Yet, on page 470 of the 1634 treaty pages published in September 2014, citizens could discover (cf. Article 14.16 CETA of the 2014 draft text - now Article 30.6 in the revised draft text published in February 2016) that they will have neither private rights under CETA nor effective judicial remedies in domestic courts against violations of FTA rules that adversely affect domestic citizens.

- In its external relations, the Union shall 'contribute to ... the strict observance of international law' (Article 3:5 TEU) in view of the lack of any conferral of EU powers to violate international treaties enacted by national and EU parliaments for the benefit of citizens. Yet, the CJEU refuses to enforce EU compliance with UN and WTO dispute settlement rulings without offering EU 'violation victims' and 'retaliation victims' effective legal and judicial remedies or financial compensation of their injuries suffered from, e.g., illegal trade restrictions by the EU. ${ }^{31}$

- Even though EU law protects rights of 'everyone ... to an effective remedy' (Article 47 EUCFR), only foreign investors have privileged access to investor-state arbitration under CETA. Private arbitrators may order governments to grant financial compensation in the order of billions of Euros through secretive arbitration circumventing the constitutional constraints under EU law. ${ }^{32}$ Similar to the assertion by EU institutions of exclusive rights to invoke and enforce WTO obligations visà-vis EU member states in EU courts without corresponding rights of citizens and of EU member states to judicial protection of 'strict observance of international law' (Article 3 TEU) by the EU itself $^{33}$, also Article 30.6 CETA excludes effective judicial remedies of EU citizens against EU violations of CETA law and dispute settlement rulings under CETA.

\section{Why CETA and TTIP risk undermining rights of citizens in transatlantic relations}

According to the revised text of Article 30.6 CETA on 'Private Rights' (as published online in February 2016),

'(n)othing in this Agreement shall be construed as conferring rights or imposing obligations on persons other than those created between the Parties under public international law, nor as permitting this Agreement to be directly invoked in the domestic legal systems of the Parties.

A Party shall not provide for a right of action under its domestic law against the other Party on the ground that a measure of the other Party is inconsistent with this Agreement.'

This provision goes beyond similar provisions in other recent FTAs of the EU such as Article 17.15 on 'No Direct Effect' in the EU-Singapore FTA initialed and published online in September 2013:

'For greater certainty, nothing in this Agreement shall be construed as conferring rights or imposing obligations on persons, other than those created between the Parties under public international law.'

\footnotetext{
${ }^{31}$ Cf. A.Thies, International Trade Disputes and EU Liability (OUP 2013).

${ }^{32}$ An example is the pending arbitration by the Swedish nuclear company Vattenfall requesting 3.5 billion Euros of damages from Germany as compensation of lost profits due to the German decision to phase-out the production of nuclear energy in Germany in the aftermath of Japan's nuclear disaster at Fukushima; ICSID arbitration Case No. ARB/12/12.

${ }^{33}$ Cf. E.U.Petersmann, Why Do the EU and its Court of Justice Fail to Protect the 'Strict Observance of International Law' (Article 3 TEU) in the World Trading System and in other Areas of Multilevel Governance of International Public Goods? in: C.Herrmann et alii (eds), Trade Policy between Law, Diplomacy and Scholarship: European Yearbook of International Economic Law (Springer 2015), 145-189.
} 
While the EU rightly insists on protecting its 'acquis communautaire' vis-à-vis EFTA states and other associated trading partners, Article 14.16 CETA - by excluding individual rights under CETA and effective judicial remedies of citizens against violations of CETA rules - runs counter to the EU treaty obligations (e.g. in Articles 2, 3 and 21 TEU) to protect citizens, rule of law and other 'EU values' and 'constitutional principles' also in the EU's external relations. The EU Commission never publicly explained why - contrary to the EU Treaty requirement to contribute 'in its relations with the wider world ... to the protection of its citizens' (Article 3:5 TEU) in conformity with the 'principles which have inspired (the EU's) own creation, development and enlargement' (Article 21 TEU) and the transnational rights of citizens under EU constitutional law ${ }^{34}$ - it has begun excluding (since about 2006) its legal and judicial accountability vis-à-vis EU citizens for violations of FTA rules and obligations. Inofficially, EU officials admit their desire to benefit - like Canadian and US trade politicians - from lack of judicial accountability for their non-compliance with FTA and WTO obligations and for injuries caused to EU citizens thereby. ${ }^{35}$ Officially, the EU's main argument against 'direct effect' of WTO rules and against 'consistent interpretations' of EU law in conformity with WTO dispute settlement rulings is its power-oriented claim of 'political freedom of maneuver' ${ }^{36}$ Arguably, such 'Hobbesian claims' - even though they have been accepted by the CJEU in order to justify its judicial self-restraint to refrain from reviewing the legality of EU acts in the light of WTO law and UN conventions (like UNCLOS, UN air transport and environmental conventions) - are inconsistent with

- the EU's constitutional requirements of 'strict observance of international law' (Article 3 TEU) and judicial protection of rule of law (Article 19 TEU);

- the 'coherence-' and 'consistent-interpretation' requirements of domestic and international legal systems (e.g. Articles 21 TEU, XVI:4 WTO, 3 DSU);

- the 'network conception' linking global trading communities (e.g. interested in reducing transaction costs for global supply chains and 'providing security and predictability to the multilateral trading system' as prescribed in Article 3 DSU);

- multilevel judicial administration of justice and judicial comity among domestic and international courts committed to protecting rule of law;

- the EU principles of 'conferral' of limited competences and of their 'proportionate' use (cf. Article 5 TEU); and

- the constitutional rights of EU citizens (e.g. under Articles 16, 17, 47, 52 EUCFR) which also limit EU powers in the trade policy area and in the implementation of FTAs inside the EU.

As illustrated by the 'Kadi-jurisprudence' of the CJEU emphasizing the constitutional restraints of UN and EU actions ${ }^{37}$, EU power politics ignoring 'strict observance of international law' (Article 3 TEU) to

${ }^{34}$ Apart from the 'common market freedoms', see the additional rights protected by the EUCFR, such as transnational economic freedoms 'in conformity with Union law' (Article 16), rights of access to documents (Article 42), and rights to effective judicial remedies (Article 47 EUCFR).

${ }^{35}$ On the legal incoherence of the various claims by EU advocates (e.g. that GATT/WTO rules are less precise and less unconditional than EU customs union rules, or that WTO safeguard, reciprocity and dispute settlement provisions exclude 'direct effect'), see Petersmann (note 33).

${ }^{36}$ The term 'freedom of manoeuvre' continues to be used by both the political EU institutions and the CJEU (e.g. in Joined cases C-120 and C-121/06 P, FIAMM, ECR 2008 I-6513, para. 119) as the main justification for their disregard of legally binding UN conventions, WTO rules and WTO dispute settlement rulings. The most recent CJEU judgment (Case C-21/14 P Rusal, judgment of 16 July 2015) justifies 'the settled case-law of the Court that, given their nature and purpose, those (WTO) agreements are not in principle among the rules in the light of which the Court is to review the legality of measures adopted by the EU institutions', essentially on utilitarian grounds such as the 'lack of reciprocity' by the EU's most important trading partners (paras. 38-39). Yet, as recognized by the CJEU in its Kupferberg-judgment of 1982, 'the fact that the courts of one of the parties consider that certain of the stipulations in the agreement are of direct application whereas the courts of the other party do not recognize such direct application is not in itself such as to constitute a lack of reciprocity in the implementation of the agreement' (ECJ, Case 104/81, ECR 1982, 3644, para. 18).

${ }^{37}$ Cf. Avbelj/Fontanelli/Martinico (note 1). 
the detriment of equal rights of citizens lacks constitutional justification. It runs counter to the EU's legal obligations (e.g. under WTO and EU law) to terminate illegal trade restrictions and protect rule of law and judicial remedies of citizens. ${ }^{38}$ Persistent EU violations of 'PGs treaties' approved by parliaments for the benefit of citizens risk undermining not only general consumer welfare, but also democracy, rule of law and transnational 'aggregate PGs'. To regain legitimacy and enhance accountability for abuses of power, the EU must 'contribute to the protection of its citizens' through 'strict observance of international law' (Article 3:5 TEU), including treaties approved by parliaments in order to protect transnational PGs through rules-based cooperation among citizens. Respect for the 'constitutional nationalism' and 'dualist legal traditions' in North-American democracies and for the 'executive dominance' of their NAFTA institutions offers no justification for the EU institutions to use FTAs for undermining individual rights and judicial remedies of EU citizens vis-à-vis EU institutions.

\section{Transparent, Democratic Governance of Transatlantic Market Regulations?}

'Transparency' refers not only to the public disclosure and accessibility of information, but also to its readability and comprehensibility. Most EU citizens remain 'rationally ignorant' vis-à-vis onlinepublications of draft treaty texts in English language with more than 1600 pages on complex, technical and legal issues (like thousands of product and production standards and market access commitments in diverse services sectors) that have been secretly negotiated by EU diplomats invoking outdated paradigms of diplomatic privileges and foreign policy discretion. If citizens - as suggested by Rawls, 'think of themselves as if they were legislators and ask themselves what statutes, supported by what reasons satisfying the criterion of reciprocity, they would think it most reasonable to enact ${ }^{39}$, they have good reasons to insist on transparent, democratic rule-making and on replacing the 'anti-citizen clause' in Article 30.6 CETA by explicit FTA rules on 'protection of citizens', as required by Articles 3 and 21 TEU, for instance by providing:

'This Agreement aims at placing Canadian (US) and EU citizens at the heart of CETA (TTIP) by protecting their rights and rule of law in transatlantic cooperation, including rights under the EU Charter of Fundamental Rights'.

Why is it only in the Preamble of CETA that diplomats refer to 'human rights and the rule of law'? Placing citizens at the heart of CETA would respond to the 'cosmopolitan foreign policy mandate' in Article 21 TEU by empowering citizens to act as transnational 'agents of justice', main economic and 'republican actors' in transatlantic cooperation, and to assume their republican and cosmopolitan responsibilities for collective protection of transatlantic PGs. Citizen-oriented FTA provisions would also set incentives for national, European and transatlantic dispute settlement bodies to interpret and enforce transatlantic FTAs in conformity with the rights of citizens and prevent disputes through mutually 'consistent interpretations' of multilevel regulation of transatlantic cooperation for the benefit of citizens.

\footnotetext{
${ }^{38}$ Cf. Petersmann (note 33). The invocation by EU trade diplomats of Article 22 DSU is misleading in this context: Article 22 envisages mutually agreed compensation only as an option for avoiding lawful sanctions, yet without justifying the maintenance of illegal trade restrictions.

${ }^{39}$ J.Rawls, The Idea of Public Reason Revisited, 64 Chikago Law Review (1997), 765, 769 (citizens 'fulfil their duty of civility and support the idea of public reason by doing what they can to hold government officials to it').
} 


\section{EU citizen rights to transparent, democratic self-governance}

Discussion of democracy since Plato and Aristotle has not produced a universally accepted 'mainstream theory' on the prescriptive (normative) and descriptive (empirical) definitions of democracy ${ }^{40} \mathrm{UN}$ law and UN human rights conventions neither precisely define nor effectively enforce their 'principles of democracy'. ${ }^{41}$ The Lisbon Treaty prescribes 'democratic principles' (e.g. in Articles 2, 6, 9-12 TEU) in terms of multilevel constitutional, parliamentary, deliberative and participatory democracy that complement the diverse national democratic traditions in order to protect the basic constitutional and democratic values in EU law and governance, such as protection of individual and democratic autonomy of EU citizens and of 'the peoples of Europe' (Article $1 \mathrm{TEU}$ ) in multilevel governance of PGs. ${ }^{42}$ Most external EU agreements include human rights provisions aimed at justifying and enforcing 'human rights conditionality' vis-à-vis third states. As national and European Parliaments have given no mandate to EU diplomats to exclude individual rights and judicial remedies in FTAs, 'anti-citizen clauses' (like Article 30.6 CETA) run counter to the 'cosmopolitan foreign policy mandate' in Articles 3 and 21 TEU and undermine 'republican citizen participation' in multilevel protection of PGs. The 'executive dominance' and inadequate 'democratic public reason' in intergovernmental FTA negotiations illustrate how national and European parliaments neglect their democratic responsibilities to protect the equal rights and democratic representation of EU citizens. As already emphasized in the French Declaration of the Rights of Man and the Citizen $(1789)^{43}$, the prioritization of rights of governments, 'disempowerment' of citizens, and inadequate judicial 'checks and balances' contribute to government failures to protect PGs effectively (like rule of law in transatlantic economic cooperation). Comparative institutionalism offers vast empirical evidence that citizen-driven 'cosmopolitan legal regimes' with multilevel judicial remedies - like international contract and commercial law, investment law, regional human rights law, European common market and competition law, rights-based FTAs, international consular and criminal law conventions - have realized their legal objectives more effectively through multilevel legal and judicial protection of cosmopolitan rights than Westphalian 'top-down' treaty regimes prioritizing rights of governments without protecting rights of citizens. ${ }^{44}$

Constitutional democracies and modern treaties increasingly promote 'internal transparency' (e.g. duties pursuant to Article 218:10 TFEU to inform the European Parliament of the EU's international treaty negotiations), 'external transparency' (e.g. duties of EU institutions pursuant to Article 11:2 TEU to engage in 'civil society dialogues' ), 'legal' and 'institutional transparency' in order to justify law and governance vis-à-vis citizens, for instance in order to enhance the 'input legitimacy' of intergovernmental rule-making through democratic participation, accountability of governments, democratic persuasion

${ }^{40}$ If defined as 'government by discussion' based on 'power of the people', democracy has even been described as 'a highflown name for something that does not exist': G.Sartori, The Theory of Democracy Revisited: Part One (Chatham House 1987), at 7.

${ }^{41} \mathrm{UN}$ human rights law recognizes citizens and peoples as holders of constituent powers who delegate only limited 'constituted powers' to governments subject to 'inalienable' human and democratic rights, including the entitlement of 'everyone ... to a social and international order in which the rights and freedoms set forth in this Declaration can be fully realized' (Article 28 UDHR). The UN Democracy Fund financially supports 'democracy-building' as 'one of the universal and indivisible core values and principles of the United Nations'. Yet, UN practices refrain from imposing 'democratic conditionality' visà-vis the many UN member states that lack democratic governance.

${ }^{42}$ Cf. A. von Bogdandy, The European Lesson for International Democracy: The Significance of Articles 9-12 EU Treaty for International Organizations, EJIL 23 (2012), 315-334. On democratic nation states, EU citizenship, cosmopolitan rights and civil society actors as complementary bases for the democratization of multilevel governance see: A.Peters, Dual Democracy, in: J.Klabbers/A.Peters/ G.Ulfstein (eds), The Constitutionalization of International Law (OUP 2009), $153 \mathrm{ff.}$ See also: J.Wouters et alii (eds), Global Governance and Democracy. A Multidisciplinary Analysis (Elgar 2015).

${ }^{43}$ Cf. its Preamble: 'Considering that ignorance, forgetfulness, or contempt of human rights are the sole causes of public misfortune and government depravity'.

${ }^{44}$ Cf. E.U.Petersmann, International Economic Law in the 21st Century. Constitutional Pluralism and Multilevel Governance of Interdependent Public Goods (Hart 2012), at 145 ff; F.Wilman, Private Enforcement of EU Law Before National Courts (Elgar 2015). 
and predictability of rules. Similarly, Article 1 TEU defines the EU as 'an ever closer union among the peoples of Europe, in which decisions are taken as openly as possible and as closely as possible to the citizen'. Article 10:3 TEU adds that '(e)very citizen shall have the right to participate in the democratic life of the Union': 'Decisions shall be taken as openly and as closely as possible to the citizen'. Article 11 TEU specifies related legal obligations of the EU institutions, which

- 'shall ... give citizens and representative associations the opportunity to make known and publicly exchange their views in all areas of Union action' (para.1);

- 'shall maintain an open, transparent and regular dialogue with representative associations and civil society' (para.2); and

- 'shall carry out broad consultations with parties concerned in order to ensure that the Union's actions are coherent and transparent' (para.3).

Article 15:3 TFEU and Article 42 EUCFR supplement these transparency principles by recognizing corresponding individual rights: '(a)ny citizen of the Union, and any natural or legal person residing ... in a Member State, shall have the right of access to documents of the Union institutions, bodies, offices and agencies... subject to the principles and the conditions to be defined in accordance with this paragraph'. The implementing Regulation 1049/2001 regarding public access to EU documents aims 'to ensure the widest possible access to documents'; it is supplemented by rules of the EU institutions protecting the confidentiality of certain documents, as clarified in the jurisprudence of European courts on the legal and judicial 'balancing' of the transparency and confidentiality requirements. ${ }^{45}$ Over the past years, many international organizations - including also UN bodies, the WTO, ICSID and UNCITRAL - have strengthened 'rights to know' and corresponding transparency obligations as integral parts of ever more national and international legal systems, for instance by actively promoting

- public access to trade, investment and other legal documents;

- public court meetings in economic and human rights adjudication; and

- rights of third parties (e.g. amici curiae) to make submissions to transnational dispute settlement bodies. $^{46}$

\section{The EU Commission's 'transparency initiative' and 'cosmopolitan public reason'}

Lack of information on confidential treaty negotiations by the EU Commission prompted the European Parliament to veto twice international draft agreements (i.e. the SWIFT agreement in February 2010 and the Anti-Counterfeiting Trade Agreement in July 2012). Following repeated complaints from the European Parliament, civil society and from the European Ombudsman over excessive confidentiality of TTIP negotiations and related documents, the European Commission launched - in March 2014 - a public consultation on investment protection and investor-state dispute settlement (ISDS) rules; it received almost 150.000 replies, mostly opposing the proposed investment protection and ISDS rules. In response to these democratic pressures, the EU Council finally disclosed its TTIP negotiations mandate of 2013 in October 2014. EU Trade Commissioner Malmström launched a new 'transparency strategy' in November 2014 aimed at helping 'to ensure greater access to trade documents by the general public and the European Parliament, and legitimacy of EU trade policy at large'. ${ }^{47}$ In response to the criticism voiced by civil society, the European Parliament's resolution of 8 July 2015 recommended to the European Commission to re-consider many aspects of the TTIP negotiations, including proposals to replace the ISDS mechanism by a new system of public law courts. Yet, also this parliamentary

\footnotetext{
${ }^{45}$ Cf. C.Herrmann, Transleakancy, in: C.Herrmann et alii (note 33), 39-46.

${ }^{46}$ On transparency in international law-making and adjudication see: A.Bianchi/A.Peters (eds), Transparency in International Law (CUP 2013).

${ }^{47}$ European Commission, Communication concerning transparency in TTIP negotiations, 25 November 2014 (C 20149052 final).
} 
resolution nowhere mentions the EU mandate to 'place the individual at the heart of its activities' (Preamble EUCFR).

In order to limit 'democracy deficits' in multilevel governance of international PGs, constitutional, parliamentary, participatory and deliberative democracy empowering national and EU citizens need to be supplemented by 'cosmopolitan democracy' empowering also transnational 'stakeholder communities' through 'republican rights' to hold multilevel governance institutions more accountable, for instance by interpreting international treaties with legislative functions for transnational PGs similar to democratic legislation adopted by parliaments so as to protect rights of citizens, rule of law and 'access to justice' in conformity with national and EU constitutional law. Just as 'constitutional democracy' inside states enables citizens to challenge 'market failures' as well as 'governance failures' through countervailing rights and remedies, so can 'cosmopolitan democracy' contribute to promoting 'public reason' and equal cosmopolitan rights by enabling citizens to invoke and progressively clarify 'as openly as possible and as closely as possible to the citizen' (Article 1 TEU) - international PGs regimes with due respect for diverse democratic contexts. Citizen-oriented interpretations of international trade rules increase the accountability and democratic capability of the EU to protect its constitutional values of freedom, equality, rule of law, non-discrimination and justice (cf. Article 2 TEU) in transnational trade relations with other constitutional democracies through multilevel legal rights and judicial remedies. ${ }^{48}$ Authoritarian conceptions of FTAs - by treating citizens as mere objects rather than legal subjects of FTAs and depriving citizens of effective judicial remedies in domestic courts (e.g. by excluding 'direct applicability' of FTA rules) - disfranchise and alienate citizens; they weaken the legal capacity of democratic governance institutions to resist rent-seeking interest group pressures to redistribute domestic income through welfare-reducing trade restrictions favoring powerful interest groups (e.g. European banana trading companies that successfully lobbied for illegal EU import restrictions from 1992-2012 redistributing billions of dollars as in a banana republic).

The absence of any public discussion so far - by EU citizens, national and European Parliaments - of the 'disempowerment' of citizens through the EU's recent FTAs illustrates why increased transparency of FTA negotiations is a precondition for more effective democratic control and accountability of international law-making. Violations of international rule of law have become systemic in ever more areas of European integration since the global financial crisis in 2008, the 'Euro-crises' since 2010, and the EU's 'border protection'- and 'immigration-crises' since 2014, resulting in persistently decreasing confidence of EU citizens in EU governance. ${ }^{49}$ The secretive CETA negotiations and the intergovernmental exclusion of rights and effective remedies of adversely affected citizens (other than powerful foreign investors) confirm the fears in civil society that FTAs risk legitimizing regulatory 'topdown harmonization' (e.g. of product and production standards) in response to special interest advocacy (e.g. by agricultural, biotech, tobacco lobbies and bureaucratic self-interests).

\section{Democratic legitimacy of FTA negotiations, ratification and implementation?}

The democratic legitimacy of (a) intergovernmental negotiations, (b) conclusion and (c) implementation of the CETA and TTIP may be evaluated differently:

\footnotetext{
${ }^{48}$ On public reason as a ‘collective capability' see: E.I.Kelly, Public Reason as a Collective Capability, in: Rutgers Law Journal 43 (2012), 295-316. 'Public reason' is less demanding than the 'discourse principle' of J.Habermas, The Inclusion of the Other: Studies in Political Theory (MIT Press 1998), at 39 ff: 'Only those norms can claim validity that could meet with the acceptance of all concerned in practical discourse.' Arguably, Habermas' requirement of 'fully inclusive, real discourse' is difficult to reconcile with the 'rational ignorance' and limited, cognitive capacities of individuals regarding collective supply of global PGs affecting billions of people in diverse countries with diverse democratic preferences; cf. A.Kuper, Democracy Beyond Borders: Justice and Representation in Global Institutions (CUP 2004), 194 ff.

${ }^{49}$ Cf. J.Zalc, Overcoming Democratic Breakdown in the EU, Fondation Robert Schuman, European Issues No 333 of 18 November 2014, at 1.
} 
1. At the current stage of treaty negotiations, constitutional, representative, participatory and 'deliberative democracy' require parliaments and civil society to insist on taking 'decisions as openly and as closely as possible to the citizens' (Article 10 TEU) and on respecting the 'cosmopolitan mandate' of Article 21 TEU to protect equal rights and remedies of citizens as 'democratic principals' and main economic actors in FTAs. Inclusive consultations during FTA negotiations must go beyond 'stakeholder consultations' with selected business representatives, 'civil society dialogues' with selected civil society representatives, EU press conferences and incomplete EU website information. The new 'transparency initiative' for the EU's common commercial policy is to be welcomed in view of the existential importance of transatlantic FTAs for the jobs, income, rights and welfare of millions of EU citizens. ${ }^{50}$ The lack of effective parliamentary participation in the design and drafting of CETA entailed that the EU Commission later opposed demands to re-open and re-negotiate the CETA rules on ISDS. Exclusion of direct invocation of FTA provisions in domestic legal systems (e.g. by Article 30.6 CETA) risks rendering domestic legal and judicial remedies ineffective for resolving transatlantic disputes; it illustrates why - from the point of view of citizens and their constitutional rights - secretive intergovernmental negotiations are far more dangerous than transparent parliamentary legislation. If FTA provisions cannot be invoked in domestic judicial proceedings, domestic courts will be incapable of administering justice in disputes over compliance with FTA rights and obligations.

2. At the level of treaty ratification, many EU member states claim that the broad regulatory scope of transatlantic FTAs (e.g. regarding subsidies, investments, movements and professional qualifications of natural service suppliers, telecommunications, intellectual property, labor rights, environmental protection) requires approval of CETA and TTIP also by national parliaments as 'mixed agreements'. Both national parliaments in Europe and in the USA (e.g. in view of the trade promotion authority granted by the US Congress for 'fast track approval' of FTAs) and the European Parliament are likely to focus on (dis)approval of the draft treaty as a whole without insisting on re-negotiation of specific treaty provisions. Without better information and preparation of national parliaments, parliamentary ratification of CETA and TTIP as 'mixed agreements' could delay their entry into force by 2 years, especially if national parliaments link ratification to other political demands (e.g. Bulgarian parliamentarians having already requested visa-free travel between Bulgaria and the USA as a condition for ratifying TTIP). Approval by the European Parliament might also be preceded by another request for an advisory opinion by the CJEU on the consistency of FTAs with EU law (pursuant to Article 218:11 TFEU). ${ }^{51}$ Civil society opposition to TTIP has so far focused on vague fears of TTIP leading to a 'race to the bottom' in levels of product and production standards, by-passing parliamentary decision-making, and giving undue weight to trade and investment rather than to health, environmental, social, labor and consumer interests. Such fears are increasingly countered by claims of the EU Commission that TTIP will neither lower the existing level of EU protection of social rights, public health and the environment nor prejudge the sovereign 'freedom to regulate' at levels of protection decided democratically.

3. As regards the implementation of future FTAs, citizens and parliaments should insist on their republican experience that multilevel democratic and judicial rights and remedies of citizens including EU law 'rights to an effective remedy and a fair trial' (Article 47 EUCFR) and duties to publicly justify 'any limitation on the exercise of rights and freedoms' (Articles 52 EUCFR, 296 TFEU) - have proven to be the most effective guarantees of rule of law, 'protection of

\footnotetext{
${ }^{50}$ A recent illustration is the CJEU judgment of 6 October 2015 invalidating the EU-USA 'safe harbour agreement' on transfers of data in view of their inadequate legal and judicial protection in the USA against disproportionate mass surveillance by the US National Security Agency.

${ }^{51}$ Such a request was already made by the EU Commission in respect of the EU-Singapore FTA and has not yet been decided by the CJEU, thereby delaying the entry into force of this FTA.
} 
citizens' and 'strict observance of international law' (Article 3 TEU). The transformation of the 1995 'New Transatlantic Agenda' into the 1998 'Transatlantic Economic Partnership' led to the establishment of intergovernmental, inter-parliamentary and civil society institutions without an adequate legal framework for protecting open markets and preventing or settling transatlantic disputes. Even if TTIP negotiations are committed to maintaining the regulatory autonomy and democratic law-making procedures both in the EU and in the USA, the objective of designing TTIP as a 'living' and 'transformative model agreement' for multilevel governance of transnational PGs in the $21^{\text {st }}$ century requires embedding transatlantic FTAs into the common American and European traditions of 'multilevel republican constitutionalism' so that the past 'disconnected top-down governance' in transatlantic relations can become progressively 'constitutionalized' by protecting cosmopolitan rights, democratic responsibilities and judicial remedies of citizens.

\section{Investor-state arbitration rather than equal rights of citizens to effective remedies?}

The negotiation directives for TTIP, which were unanimously approved by the EU Council in June 2013, also called for investment protection and ISDS on the condition that the final outcome meets the EU interests. In view of the strong public interest in this issue, the EU Commission launched a public consultation - from March to July 2014 - on the proposed EU approach in order to seek feedback on the following twelve key issues:

1. Scope of the substantive investment protection provisions.

2. Non-discriminatory treatment for investors.

3. Fair and equitable treatment.

4. Expropriation.

5. Ensuring the right to regulate and investment protection.

6. Transparency in ISDS, multiple claims and relationship to domestic courts.

7. Arbitrators' ethics.

8. Conduct and qualifications.

9. Reducing the risk of frivolous and unfounded cases.

10. Allowing claims to proceed (filter).

11. Guidance by the parties on the interpretation of the agreement.

12. Appellate mechanism and consistency of rulings.

The Commission's Report on these consultations ${ }^{52}$ acknowledged that $97 \%$ of the almost 150 '000 submissions made by EU citizens, companies and NGOs revealed a 'huge skepticism' by civil society on the proposed treaty provisions on investor protection. Critics argue, inter alia, that arbitration procedures risk limiting the regulatory discretion of states by circumventing existing domestic legal standards and judicial procedures so as to privilege foreign investors at potentially immense costs for domestic tax-payers. The Report identified in particular four areas for further improvements of ISDS:

- the protection of the right to regulate;

- the establishment and functioning of arbitral tribunals;

- the relationship between domestic judicial systems and ISDS; and

- the review of ISDS decisions through an appellate mechanism.

\footnotetext{
${ }^{52} \mathrm{Cf}$. EU Commission, Report on Online public consultation on investment protection and investor-to-state dispute settlement in TTIP, Staff Working document of 13.1.2015 SWD (2015).
} 


\section{ISDS risks undermining constitutional 'rule of law'}

ISDS emerged since the 1960s as a substitute for perceived weaknesses of judicial systems inside lessdeveloped capital-importing countries. Inside TTIP countries, there is no constitutional justification for preventing access by all investors to the highly developed, domestic judicial systems to ensure 'rule of law', including precise and unconditional FTA rules as integral parts of EU law. Hence, a large part of the respondents to the EU's online consultation considered that domestic courts should be exclusively used to settle disputes between states and foreign investors in view of the fact that the EU and the USA have democratic legal systems and experienced judicial systems that protect property rights and other fundamental rights, including rights of foreigners. The TTIP negotiators should focus on improving domestic legal and judicial remedies (e.g. in order to prevent 'negative discrimination' of local companies, avoid parallel proceedings, and ensure application of international investment rules by domestic courts). They should follow the precedent of the 2004 FTA between Australia and the USA, which abstained from providing for investor-state arbitration because of the fact that both countries have developed legal systems for resolving disputes between foreign investors and government. Reference is made also to investor-state arbitration practices (e.g. the Loewen vs United States and Mondev vs United States arbitral awards under Chapter 11 NAFTA) as evidence that investor-state arbitration may not offer foreign investors effective remedies against alleged failures in US local judiciaries. ${ }^{53}$ The pending Vattenfall vs Germany arbitration under the Energy Charter Treaty is cited as evidence for the dangers of foreign arbitrators circumventing national and European constitutional law by possibly awarding compensation claims amounting to billions of Euros. As EU and US law recognize legal presumptions that precise and unconditional treaty provisions protecting individual rights may be invoked by private parties in domestic courts as 'self-executing', 'directly applicable' rules or as relevant legal context for 'consistent interpretations' of applicable domestic law, TTIP negotiators should secure the effectiveness of domestic legal and judicial remedies for the benefit of all citizens, rather than engage in reverse discrimination of domestic investors in international treaties with legislative functions for multilevel protection of transnational PGs. If US negotiators oppose 'direct applicability' of TTIP provisions in US courts, the TTIP agreement could leave it to European courts to decide whether - and which - treaty rules can be invoked in European jurisdictions by adversely affected citizens so as to protect their fundamental rights (e.g. under Arts 16, 17, 47 and 52 EUCFR). A non-discriminatory 'constitutional approach' to investment protection could promote both international investment law (e.g. by promoting domestic enforceability of international investment treaties in domestic courts) as well as multilevel 'republican governance' of transnational PGs based on international 'PGs regimes'. Jurisdiction of domestic courts - not only for foreign investors but for all citizens adversely affected by FTA rules and practices - would avoid the risk that the CJEU - in view of its increasing reluctance to approve limitations on the jurisdiction of the CJEU by international jurisdictions (like a European Patent Court, the European Court of Human Rights, WTO dispute settlement bodies) $)^{54}$ - might find TTIP provisions on transnational ISDS to be incompatible with EU law.

On 12 November 2015, the EU Commission released a new proposal for TTIP provisions on ISDS replacing investor-state arbitration by a new 'investment court system' based on a Tribunal of First Instance (composed of 15 public law judges: 5 judges from EU member states, 5 judges from the USA, and 5 judges from third countries) and a permanent Appeal Tribunal composed on 6 public law judges ( 2 from EU member states, 2 from the USA, and 2 judges from third countries). In contrast to Article 42 of the ICSID Convention which defines the applicable law in investor-state arbitration as including

\footnotetext{
${ }^{53}$ The Loewen case was about procedural biases in local US courts against a Canadian investor; the Mondev case challenged an immunity clause preventing the foreign investor to sue the Boston Redevelopment Authority; for a discussion of these two ICSID disputes from the perspective of 'denial of justice' see: R.D.Bishop/J.Crawford/W.M.Reisman, Foreign Investment Disputes. Cases, Materials and Commentary (Kluwer 2005), at $953 \mathrm{ff}$.

${ }^{54}$ Cf. B. de Witte, A Selfish Court? The Court of Justice and the Design of International Dispute Settlement Beyond the European Union, in: M.Cremona/A.Thies (eds), The European Court of Justice and External Relations Law. Constitutional Challenges (Hart 2014), 33-46.
} 
the domestic law of the host state, international law and the investor-state concession contracts ${ }^{55}$, the applicable law in the proposed 'investment court system' is limited to the TTIP rules (cf. Article 8.31 CETA). As simultaneous proceedings before domestic and international courts are excluded, this artificial fragmentation of the applicable law and jurisdictions - i.e. domestic jurisdictions that are prevented from applying relevant TTIP rules and principles, and international investment courts that are prevented from applying the domestic law of the host state and the investor-state contracts - reintroduces the procedural and substantive legal disadvantages which Article 42 of the ICSID Convention was designed to avoid, for instance many years of litigation in domestic courts over the domestic law dimensions of the dispute that are followed by additional years of litigation in international courts over the different international law dimensions of the same dispute - a proven nightmare especially for small enterprises. In a legal opinion published in February 2016, the German Federation of Judges criticized the proposed international investment court as being neither necessary (e.g. in view of the better legal qualifications, impartiality and greater independence of national and EU courts) nor lawful (e.g. in view of unjustified limitations of national and EU jurisdictions to protect rule of law in conformity with EU law). ${ }^{56}$

\section{Multilevel judicial protection of equal rights and rule of law as a transnational PG}

The efforts by EU executives aimed at preventing domestic courts from holding EU institutions accountable for violations of FTA obligations undermine rights and remedies of EU citizens and the effectiveness of ISDS. Non-discriminatory legal and judicial remedies of all citizens in domestic and EU courts against harmful violations of FTA rules are more consistent with constitutional principles of justice than procedural privileges of foreign investors in specialized investment courts. ${ }^{57}$ The 'jurists of recognised competence' proposed by the EU (e.g. in Article 10:7 EU of its draft proposal of 12 November 2015) risk lacking the qualifications required for appointment to the highest judicial offices inside the EU; as regards judges from outside the EU, they risk to ignore EU constitutional law. Apart from unjustified discrimination in favor of foreign investors over domestic investors and other adversely affect EU citizens, the EU proposals fail to protect 'rule of law' as a constitutional restraint on 'rule by law' so as to 'ensure that in the interpretation and application of the Treaties the law is observed' (Article 19 TEU), including the EU constitutional principles of 'respect for human dignity, freedom, democracy, equality... and respect for human rights' (Article 2) and 'strict observance of international law' (Article 3 TEU). FTA provisions like Article 30.6 CETA prevent citizens and domestic courts from holding foreign investors accountable for violating FTA obligations; likewise, the TTIP investment rules proposed by the EU do not protect rights and remedies of EU citizens to hold foreign investors accountable for violating FTA obligations (e.g. for consumer, environmental and labor protection). As the 'Union's action on the international scene shall be guided by the principles which have inspired its own creation, development and enlargement' (Article $21 \mathrm{TEU}$ ) - and private enforcement of common market rules and fundamental rights in domestic courts has proven to be the most effective and democratic, decentralized remedy in European integration practices -, there are more effective, alternative ways of protecting the EU commitment to 'strict observance of international law' (Article 3 TEU), for instance by

- protecting everyone's 'right to an effective remedy before a tribunal' (Article 47 EUCFR) through individual access to domestic judicial remedies for everybody based on 'consistent interpretations' and 'direct applicability' of precise and unconditional FTA rules in domestic courts which are

\footnotetext{
${ }^{55}$ Cf. J.W.Salacuse, The Three Laws of International Investment. National, Contractual, and International Frameworks for Foreign Capital (OUP 2013).

${ }^{56}$ Cf. Deutscher Richterbund Stellungnahme 04/16 (http://www.drb.de/cms/index.php?id=952).

${ }^{57}$ Cf. M.Kumm, An Empire of Capital. Transatlantic Investment Protection as the Institutionalization of Unjustified Privilege, in: ESIL Newsletter Vol. 4 (2015), issue 3.
} 
better placed to address investor-state disputes than ad hoc arbitrators and specialized investment lawyers who risk being unfamiliar with national and European constitutional law;

- protecting individual access by all citizens adversely affected by FTA violations to a Transatlantic Market Court with a general jurisdiction for protecting 'rule of law', composed of public law judges with qualifications for appointment to the highest judicial offices in their own countries; and

- promoting 'judicial comity' and 'judicial dialogues' between national and international judges through 'preliminary rulings' or 'advisory opinion procedures' empowering national judges to request legal interpretations of FTA rules and principles from a permanent TTIP Court.

According to the CJEU, the EU is 'a community based on the rule of law' to the extent that neither the member states nor the EU institutions can avoid review of the conformity of their acts with European constitutional law. ${ }^{58}$ If the 'rule of law' requirements of the Lisbon Treaty are construed in conformity with the EU commitments to protecting 'strict observance of international law' and to 'exporting its values' (cf. Articles 3, 21 TEU), the external EU relations must remain consistent with the constitutional rights and remedies of EU citizens even if third countries - like Switzerland and NAFTA countries in their FTAs with the EU - may not be willing to limit their national jurisdictions through international common market courts. ${ }^{59}$ As illustrated by the 'constitutional pluralism' in the EU relations with EFTA states (as discussed in section II), the EU can and must protect its constitutional principles (like individual rights to effective remedies pursuant to Article 47 EUCFR) as restraints on the exercise of EU public powers even if judicial remedies and access to courts inside the jurisdiction of foreign trading partners (like Switzerland and NAFTA countries) may be regulated differently in view of their diverse constitutional traditions.

\section{Conclusion: Disfranchisement of Citizens Undermines the Legitimacy and Effectiveness of Multilevel Governance of Transnational PGs}

The EU's 'textual proposal' of February 2015 for the TTIP Chapter on 'Regulatory Cooperation' claims that the provisions - as they 'concern predominantly procedures for cooperation' and 'cannot be interpreted or applied as to oblige either Party to change its fundamental principles governing regulation in its jurisdiction, for example in the areas of risk assessment and management' - 'may not lend themselves to the application of dispute settlement rules'. Yet, experience with product standards inside the EU demonstrates that EU standards may later be challenged as inadequately protecting public interests (e.g. Mercedes Benz challenging an EU standard for automobile coolers as risking to cause fire and injure people). The different cultures of national risk-regulation in the US and international riskregulation and domestic risk-aversion inside the $\mathrm{EU}$, and the interest-driven nature of politics, have given rise to numerous transatlantic regulatory conflicts over the past decades. Conflict prevention through inclusive representation (e.g. of trade, investment, consumer, labor and environmental interests), transparent negotiations and the design of TTIP as a 'living agreement' enabling regulators to add and implement 'sectorial regulation annexes', must be supplemented by democratic scrutiny and

${ }^{58}$ Cf. Case 294/83, Les Verts v Parliament, ECR 1986 1339, para. 23. In the Kadi I and II cases, the CJEU stressed the importance of reviewing 'any Community measure' in the light of the fundamental rights of citizens in order to ensure 'a Community based on the rule of law'. In the $E \& F$ case of 2010, the CJEU confirmed the constitutional character of the rule of law principle by referring to the 'Union based on the rule of law'; Case C-550/09, E \& F, ECR 2010 I-6209, para. 44. In its advisory opinion 1/2009 of 8 March 2011 on the proposed establishment of a European Patent Court, the CJEU interpreted EU law as guaranteeing a complete system of legal and judicial remedies and procedures for the control of the legality of acts of EU institutions (para. 70).

${ }^{59}$ In Case C-336/10, Air Transport Association of America v Secretary of State for Energy, ECR 2011, para. 101, the CJEU confirmed: 'Under Article 3(5) TEU, the European Union is to contribute to the strict observance and the development of international law. Consequently, when it adopts an act, it is bound to observe international law in its entirety, including customary international law, which is binding upon the institutions of the European Union'. 
judicial remedies so as to take into account a maximum of information that is not available to central regulators and changes over time. The 'new trade strategy' announced by EU Commissioner Malmström in October $2015^{60}$ claims that TTIP and other EU trade agreements will maintain or improve the consumer protection levels and not amend the legislative and democratic decision-making procedures; the scope for autonomous rulemaking by the Commission and other regulatory agencies will remain limited. ${ }^{61}$ Yet, selfish business conduct (e.g. bribery, manipulations of environmental and financial standards) and past regulatory conflicts - e.g. regarding use of growth hormones and GMOs, discovery by US regulatory agencies of systemic cheating by European banks and automobile producers - will not magically disappear through TTIP. The 'disempowerment of citizens' weakens civil society support in challenging abuses of public and private power; it reveals 'bureaucratic hybris' and preference for selective stakeholder participation (e.g. in TTIP's Regulatory Cooperation Council) instead of general legal accountability of multilevel governance agents vis-à-vis all adversely affected citizens. EU trade diplomats have not offered convincing reasons why the EU constitutional law requirements of 'rule of law' and 'rights to an effective remedy before a tribunal' (Article 47 EUCFR) should no longer be protected in FTAs despite the past EU experience that such judicial remedies are crucial for of 'protection of citizens' and 'strict observance of international law' in EU external relations (cf. Articles 3:5, 21 TEU). Many of the past transatlantic disputes could have been avoided by stronger legal and judicial accountability of trade politicians vis-à-vis citizens, for instance if domestic courts had protected citizens against harmful violations of WTO dispute settlement rulings and WTO legal obligations approved by parliaments for the benefit of citizens. ${ }^{62}$

Since the 1960s, the internal EU common market rules and external FTAs based on GATT Article XXIV had been consistently interpreted and protected by national and European courts in terms of equal freedoms and rights of citizens rather than only as reciprocal rights of governments. Such 'consistent interpretations' and 'direct applicability' of liberal trade rules for the benefit of private economic actors and citizens was supported by the comprehensive GATT/WTO guarantees of individual access to judicial remedies, for instance in the field of GATT (Article X), the WTO Antidumping Agreement (Article 13), the WTO Agreement on Customs Valuation (Article 11), the Agreement on Pre-shipment Inspection (Article 4), the Agreement on Subsidies and Countervailing Measures (Article 23), the General Agreement on Trade in Services (Article VI GATS), the Agreement on Trade-Related Intellectual Property Rights (Articles 41-50, 59 TRIPS) and the Agreement on Government Procurement (Article XX). In contrast to this long-standing jurisprudence granting 'direct effect' to precise and unconditional FTA provisions ratified by parliaments in order to enhance equal freedoms of citizens (arguably, as 'first principle of justice') and general consumer welfare, the political EU institutions began explicitly restraining the 'direct effect' of more recent FTAs since 2006, for instance by

- general clauses in the 'final provisions' of the agreement precluding 'direct effect';

- treaty clauses that FTA dispute settlement rulings 'shall be binding on the Parties and shall not create any rights or obligations for natural or legal persons';

- clauses in the schedules of commitments to liberalize services to the effect that 'the rights and obligations arising from the list shall have no self-executing effect and thus confer no rights directly to natural or juridical persons'; or

- provisions in the Council Decision approving the FTA that 'the agreement shall not be construed as conferring rights or imposing obligations which can be directly invoked before Union or Member State courts and tribunals'. ${ }^{63}$

\footnotetext{
${ }^{60}$ Trade for All. Towards a More Responsible Trade ad Investment Policy, EU Commission 2015.

${ }^{61}$ For detailed studies see: C.Gerstetter et alii, Regulatory Cooperation under TTIP - A Risk for Democracy and Regulation? (H.Böll Stiftung Berlin 2014); A.Alemanno, The TTIP and the Parliamentary Dimension of Regulatory Cooperation (European Parliament 2014).

${ }^{62} \mathrm{Cf}$. the numerous case-studies in: Petersmann/Pollack (note 22).

${ }^{63} \mathrm{Cf}$. Semertzi (note 4 above).
} 
This study has argued that the EU's disregard for its constitutional obligation of 'strict observance of international law' (e.g. through persistent violations of GATT/WTO rules and dispute settlement findings) is just one illustration of 'systemic deficiencies' in the rule of law among and inside EU member states (like Bulgaria, Romania and Greece) that undermine multilevel EU governance (e.g. by persistent violations of EU budget and debt disciplines, EU border protection and immigration rules). ${ }^{64}$ Without rule of law, democratic majority politics lacks legitimacy, as illustrated by the past transatlantic 'banana disputes', anti-dumping disputes, 'subsidy competition' (e.g. from agricultural products to aircrafts), disputes over growth hormones, GMOs, technical barriers to trade and discrimination in government procurement, telecommunications practices, air transport regulation and intellectual property rights. ${ }^{65}$ Instead of designing transformative, transatlantic FTAs as a transatlantic 'empire of laws and not of men' (in the classic expression of James Harrington of 1656), the 'executive dominance' of CETA and TTIP negotiations and their intergovernmental 'disempowerment' of citizens risk making both Europe and the USA less democratic. ${ }^{66}$ EU institutions should be grateful to EU citizens if they assume their republican, democratic and cosmopolitan responsibilities and criticize lack of EU leadership in multilevel governance of international PGs.

\footnotetext{
${ }^{64}$ Cf. A. von Bogdandy/M.Ioannidis, Systemic Deficiency in the Rule of Law: What it is, What has been done, What can be done, in: CMLRev 51 (2014), 59-96.

${ }^{65}$ Cf. notes 22 and 62.

${ }^{66}$ See also: J.Kopstein/S.Steinmo (eds), Growing Apart? America and Europe in the 21st Century, CUP 2008.
} 

